\title{
Improving sensory acceptance and physicochemical properties by ultrasound application to restructured cooked ham with salt $(\mathrm{NaCl})$ reduction
}

\author{
Tiago Luis Barretto ${ }^{\mathrm{a}, \mathrm{b}}$, Marise Aparecida Rodrigues Pollonio ${ }^{\mathrm{c}}$, Javier Telis-Romero ${ }^{\mathrm{a}}$, \\ Andrea Carla da Silva Barretto ${ }^{\text {a,** }}$ \\ a São Paulo State University - UNESP, Institute of Biosciences, Humanities and Exact Sciences - IBILCE, Campus São José do Rio Preto, Food Engineering and Technology \\ Department - Meat and Meat Products Laboratory, Cristovão Colombo St. 2265, Zip Code 15.054-000 São José do Rio Preto, São Paulo, Brazil \\ b Federal Institute of São Paulo - IFSP, Campus Barretos, C-1 Avenue 250, Zip Code 14781-502 Barretos, São Paulo, Brazil \\ ${ }^{\mathrm{c}}$ Faculty of Food Engineering, University of Campinas, Department of Food Technology, Monteiro Lobato St 80, Zip Code 13.083-862, Campinas, São Paulo, Brazil
}

\section{A R T I C L E I N F O}

\section{Keywords:}

Sodium reduction

Pork

Microstructure

Cavitation

Meat products

\begin{abstract}
A B S T R A C T
The objective of this research was to study the effects of salt reduction and the application of ultrasound (nominal current of $600 \mathrm{~W} \mathrm{~cm}^{-2}$ for $10 \mathrm{~min}$ ) on the physicochemical properties, the microstructure and the sensory acceptance of restructured cooked ham. Four treatments with reduced salt including one with the application of ultrasound (1.5, 1.12, 0.75 and $0.75 \%$ salt + ultrasound) were produced. The treatment with $0.75 \%$ salt provided a reduction of about $30 \%$ in the sodium content. The use of ultrasound decreased the Total Fluid Release and increased the hardness. For lightness, the sample with $0.75 \%$ salt with the application of ultrasound did not differ from the control at day zero of storage. The use of ultrasound increased redness too. The ultrasound treatment caused micro fissures on the myofibrils. The sensory acceptance of restructured cooked ham with $0.75 \%$ of salt was improved with ultrasound applied. The ultrasound showed good potential for use in the production of healthier meat products.
\end{abstract}

\section{Introduction}

Most pork consumed in Brazil is in processed products, since $89 \%$ of this meat is industrialized in various products such as salami, sausages, restructured cooked ham and cooked restructured pork shoulder (ABPA, 2016). On the world stage, restructured cooked ham also appears as one of the most popular meat products among consumers (Válková, Saláková, Buchtová, \& Tremlová, 2007). Restructured cooked ham is produced exclusively from boned prime leg of pork with added ingredients and subjected to a suitable cooking process (Brazil, 2000). The ingredients used in the formulation aim to improve the product characteristics, such as salt $(\mathrm{NaCl})$, which plays an essential role in the water holding capacity, the lipid retention properties, color, flavor and texture as well as playing a part in the extraction of myofibrillar proteins and contributing to the shelf life of meat products (Ruusunen \& Puolanne, 2005).

Sodium chloride is the major source of dietary sodium (WentzelViljoen, Steyn, Ketterer, \& Charlton, 2013), and excessive sodium intake is related to increased blood pressure. This increases the risk of strokes and death from vascular diseases (Iser, Claro, Moura, Malta, \&
Neto, 2011; Vollmer et al., 2001). In this sense, there is a need to reduce the use of salt in processed meat products. However, salt reduction should not occur without effective studies, due to its technological and sensory importance for the development of meat products (Ruusunen \& Puolanne, 2005). Some studies (Bis et al., 2016; Carraro, Machado, Espindola, Campagnol, \& Pollonio, 2012) tested reformulations of meat products, partially substituting sodium chloride by potassium chloride and the results showed the possibility of producing products with lower sodium content without compromising the technical and sensory qualities. However, when used principally on its own, some studies report that $\mathrm{KCl}$ can damage the sensory acceptance of meat products by promoting bitterness, astringency and metallic taste (Askar, El-Samahy, \& Tawfic, 1994; Geleijnse, Kok, \& Grobbee, 2003; Gelabert, Gou, Guerrero, \& Arnau, 2003).

Alternative technologies have been studied aiming to promote the functional properties of food products, added to the convenience of less processing time, less water, less energy expenditure and less production of effluents and toxic substances. In this context, new processing technologies such as microwaves, pulsed electric fields, high hydrostatic pressure, ultraviolet light, ohmic heating and ultrasound are inserted

\footnotetext{
* Corresponding author.

E-mail address: andreasb@ibilce.unesp.br (A.C. da Silva Barretto).
} 
(Chemat, Zill, \& Khan, 2011; Leadley \& Willians, 2008). With respect ultrasound, several studies report (Cárcel, García-Pérez, Benedito, \& Mulet, 2012; Jayasooriya, Torley, D'arcy, \& Bhandari, 2007; McDonnell, Lyng, \& Allen, 2014b; Vimini, Kemp, \& Fox, 1983) that this technology can be useful to accelerate and intensify the extraction and diffusion of sodium and, thus, reduce the processing time. Cárcel, García-Pérez, Benedito, and Mulet (2012) emphasizes that the technology of ultrasound enables innovation in the industry by saving energy and increasing the yield and quality of the final products, meaning that this technology opens up a whole new field in food processing.

Ultrasound waves can be classified as high and low energy. Those of high energy have low frequency $(20-100 \mathrm{kHz})$ and develop higher power levels $\left(10-1000 \mathrm{~W} \cdot \mathrm{cm}^{-2}\right)$, sufficient to break intermolecular bonds, with intensities $>10 \mathrm{~W} \cdot \mathrm{cm}^{-2}$ producing a cavitation phenomenon, able to change some physical properties, catalyze chemical reactions (Jayasooriya, Torley, D'arcy, \& Bhandari, 2007) and improve mass transfer processes (Ojha, Keenan, Bright, Kerry, \& Tiwari, 2016). So, the objective of this study was to study the effects of salt reduction and the use of ultrasound on the physicochemical properties, microstructure and sensory acceptance of restructured cooked ham.

\section{Materials and methods}

\subsection{Restructured cooked ham manufacture}

Topside ham (semimembranosus and adductor muscles) $(70.1 \%$ moisture content, $21.43 \%$ protein content and $6.9 \%$ lipid content) was obtained from a local slaughterhouse (Slaughterhouse "Olhos D'água", Ipuã, Sao Paulo, Brazil). The meat was received frozen at $-18^{\circ} \mathrm{C}$, ground using a kidney plate into pieces measuring $3 \times 3 \mathrm{~cm}$, vacuumpacked and maintained in this condition for $24 \mathrm{~h}$. Thawing occurred in a refrigerator at $4^{\circ} \mathrm{C}$ for $48 \mathrm{~h}$ before the start of the processing of the ham.

The amount of sodium chloride in Brazilian restructured cooked ham is variable typically around $1.5 \%-2 \%$. So, $1.5 \%$ was chosen as the salt content used as the control. Four treatments were made for restructured cooked ham - T100: 1.5\% NaCl; T75: 1.12\% NaCl; T50: $0.75 \% \mathrm{NaCl}$ and; T50US: $0.75 \% \mathrm{NaCl}$ and subjected to ultrasound $10 \mathrm{~min}$ in a nominal current of $600 \mathrm{~W} \cdot \mathrm{cm}^{-2}$. The topside ham was mixed with brine, which was made by homogenizing of $1.5 \%$ soybean isolate protein (Bremil, Lajeado, Brazil), 0.94\% sodium-free California condiment (Fego, Goiânia, Brazil), 0.1\% monosodium glutamate (Ajinomoto, São Paulo, Brazil), 0.02\% cochineal carmine dye (Christian Hansen, Hoersholm, Denmark), 0.28\% curing salt (Kraki, Santo André, Brazil - 10\% sodium nitrite and $90 \%$ sodium chloride), $0.19 \%$ sodium erythorbate (NewMax, Americana, Brazil), $0.47 \%$ sodium tripolyphosphate (NewMax, Americana, Brazil), $0.47 \%$ sucrose (União, Sertãozinho, Brazil), $0.24 \%$ carrageenan (Indukern, Jundiaí, Brazil), $0.28 \%$ maltodextrin (Ingredion, Mogi Guaçu, Brazil). All the ingredients for the brine were mixed in a homogenizer (Fisatom, São Paulo, Brazil). The percentages of water and salt (sodium chloride) for each treatment are shown in Table 1. After the topside ham and brine had been mixed, T100, T75 and T50 were massaged in a tumbler (Frigomaq, Chapecó, Brazil) for $60 \mathrm{~min}$ (15 rpm).

T50US was subjected to ultrasound and then also massaged in the

Table 1

Percentual of water and salt of cooked ham.

\begin{tabular}{lllll}
\hline Ingredients & \multicolumn{4}{l}{ Treatments (\%) } \\
\cline { 2 - 5 } & T100 & T75 & T50 & T50US \\
\hline Water & 31.52 & 31.89 & 32.27 & 32.27 \\
Salt $-\mathrm{NaCl}$ & 1.5 & 1.12 & 0.75 & 0.75 \\
\hline
\end{tabular}

$\mathrm{T} 100=1.5 \% \mathrm{NaCl} ; \mathrm{T} 75=1.12 \% \mathrm{NaCl} ; \mathrm{T} 50=0.75 \% \mathrm{NaCl} ; \mathrm{T} 50 \mathrm{US}=0.75 \%$ $\mathrm{NaCl}$ and ultrasound. same tumbler under the same conditions as the other treatments. To apply the ultrasound in T50US, the incorporated ingredients were packed in a cylindrical stainless steel vat (21 cm diameter, $42 \mathrm{~cm}$ high) that was immersed in an ice bath and then subjected to the ultrasound waves. The system comprised a VCX-1500 ultrasound processor (Sonics \& Materials Inc., Newtown, USA) which emits waves at a frequency of $20 \mathrm{kHz}$. The processor was equipped with a Ti-6Al-4 V titanium probe that emits ultrasound in both the axial and radial directions (Sonics \& Materials Inc., Newtown, USA). The probe was immersed in the mixture and positioned in the center of the vessel.

$0.8 \mathrm{~kg}$ portions of each treatment were embedded in a $95 \mathrm{~mm}$ plastic casing (Viscofan, Navarra, Spain) and accommodated in stainless steel molds for ham. They were kept at rest at $4^{\circ} \mathrm{C}$ for $60 \mathrm{~min}$. Subsequently, the molds were immersed in water at $25^{\circ} \mathrm{C}$ in a cooking tank (Frigomaq, Chapecó, Brazil). After immersion, the temperature was adjusted to $80^{\circ} \mathrm{C}$. The cooking cycle ended when the ham reached $72{ }^{\circ} \mathrm{C}$ at its thermal center and it was promptly cooled by immersion in iced water for sixty minutes. The hams were stored at $4{ }^{\circ} \mathrm{C}$ until the beginning of the analyses. Ten restructured cooked hams were prepared per treatment in each batch. Three independent batches of the restructured cooked hams were prepared on three different days.

\subsection{Proximate analysis, $\mathrm{pH}$ and sodium content}

Moisture, ash and protein contents were determined according to the AOAC (2007) method. The lipid content was determined, following the methodology described by Bligh and Dyer (1959). Total carbohydrates were determined by a difference calculation. The $\mathrm{pH}$ was measured in triplicate for each treatment using a PG 1800 digital pH meter (Gehaka, Sao Paulo, Brazil) that was calibrated with two standard solutions ( $\mathrm{pH} 4$ and $\mathrm{pH}$ ) at room temperature, at zero-day cold storage used by inserting the probe in the piece of restructured cooked ham. The sodium content was analyzed using dry digestion (Horwitz, 2010). The homogenized samples were weighed, pre-calcinated on a hot plate and incinerated in a muffle furnace at $450{ }^{\circ} \mathrm{C}$ until the ash, free of black spots, formed. The ash was quantitatively transferred to a volumetric flask with nitric acid solution $5 \%(v / v)$ and the reading was performed using a DM-62 flame photometer (Digimed Analytical Group, São Paulo, Brazil). All assays were performed in triplicate.

\subsection{Total fluid release (TFR)}

This evaluation shows the water retention capacity in the period after cooking and also during cold storage. The hams were partially opened at one end and placed over a $250 \mathrm{ml}$ beacker for $10 \mathrm{~min}$ to collect all the exuded liquid. TFR (\%) was measured in triplicate after zero and sixty days of refrigerated storage by subtracting the weight of the ham after cooking and draining (W2) from the total weight of the ham before cooking (W1), expressed as a percentage of the total weight before cooking, according to Eq. (1).TFR $(\%)=\frac{W 1-W 2}{W 1} \times 100$

\subsection{Instrumental color}

Instrumental color was measured using a Colorflex EZ 45/0 spectrophotometer (HunterLab, Reston, US) calibrated using the black glass and white tile provided. Samples were analyzed in a $2.5 \mathrm{in}$. glass sample cup, with a 1.25 in. port insert, illuminant D65, at room temperature. The color was expressed in $L^{*}$ for lightness, $a *$ for redness and $b^{*}$ for yellowness. Four measurements were obtained for each parameter at equidistant points, by rotating the capsule. The mean of the measurements represented the reading for each sample. The measurements were performed after zero and sixty days of refrigerated storage. 


\subsection{Texture profile analysis (TPA)}

The TPA was done with a TA-XT plus texture analyzer (Stable Micro Systems, Godalming, England) and using its propriety Exponent program, version V.5.1.1.0 (Stable Micro Systems, Godalming, England), following the method described by Bourne (1978). The parameters determined were: Hardness $\left(\mathrm{N} \cdot \mathrm{cm}^{-2}\right)$ : maximum force required to compress the product; Cohesiveness: extent to which the sample could be deformed prior to rupture; Springiness: ability of sample to recover its original form after the deforming force was removed; and Chewiness: work required to masticate the sample for swallowing. The ham samples were molded with a circular stainless steel cutter (diameter $2 \mathrm{~cm}$ ) and a cylindrical probe was used $(3.6 \mathrm{~cm}$ diameter), with $50 \%$ compressions, test speed $1 \mathrm{~mm} / \mathrm{s}, n=10$. The measurements were taken after zero and sixty days of refrigerated storage.

\subsection{Thiobarbituric acid reactive substances (TBARS)}

The thiobarbituric reactive substances (TBARS) values were determined as described by Bruna, Ordonez, Fernández, Herranz, and La Roz (2001) after zero and sixty days of refrigerated storage. The amount of TBARS was expressed as mg of malonaldehyde per kilogram of sample (mg MDA $\mathrm{kg}^{-1}$ sample). Concentrations were determined at $532 \mathrm{~nm}$ and a standard curve was prepared using 1,1,3,3 tetraethoxypropane. Because the restructured cooked ham has added sodium nitrite in the formulation, $0.5 \%$ sulfanilamide in $20 \% \mathrm{HCl} v / \mathrm{v}$ was added to minimize the interference of this compound in the reaction with thiobarbituric acid (Zipser \& Watts, 1962).

\subsection{Microbiological evaluation}

Microbiological analyses were carried out on samples of the restructured cooked ham after zero and sixty days of refrigerated storage and the results evaluated in accordance with the microbiological standards established by Brazilian legislation (Brazil, 2001). The restructured cooked ham packaging was opened aseptically and $25 \mathrm{~g}$ of sample were diluted in $225 \mathrm{ml}$ of sterile peptone water (HIMEDIA, Mumbai, India) for analysis of thermo-tolerant fecal coliforms, coagulase-positive Staphylococci and sulfite-reducing Clostridia. To investigate Salmonella spp., $25 \mathrm{~g}$ of the sample was diluted with lactose broth (HIMEDIA, Mumbai, India) (Horwitz, 2010). The thermo-tolerant coliforms were investigated using the fermentation technique in multiple tubes and were expressed in most probable number (MPN) per gram of sample. Coagulase-positive Staphylococci were investigated by inoculating Baird-Parker Agar (HIMEDIA, Mumbai, India) enriched with egg yolk and 1\% potassium tellurite. Clostridia sulfite-reducers were analyzed by inoculating the samples with SPS Agar (HIMEDIA, Mumbai, India) incubated anaerobically, in duplicate, and expressed as log colony-forming units (CFU) per gram of sample.

\subsection{Sensory acceptance}

Sensory analysis was conducted after obtaining the results of the microbiological analysis, after fifteen days of refrigerated storage of the product. A group of one hundred and fifteen untrained restructured cooked ham consumers, composed of students and staff of the Institute of Biosciences, Letters and Exact Sciences of the São Paulo State University (UNESP/Ibilce), made up the team for the acceptance analysis. All the treatment samples, sliced on a plate, were coded randomly with three digit numbers and presented to the consumers randomly in a sequential monadic manner as described by Meilgaard, Civille, and Carr (1999). The sensory test was held in one session with four samples. All consumers evaluated one sample of all treatments in a randomized order, in single cabins with day light in the Sensory Analysis Laboratory of the Food Engineer and Technology Department UNESP. Unsalted crackers and water at room temperature were provide to clean the palate between each sample. Using a structured 9-point hedonic scale, anchored at the extremes by 9 - extremely desirable and 1 - extremely undesirable, consumers evaluated the following attributes: color, taste, texture and overall acceptance. And on a 5-point scale, anchored at the extremes by 1 - certainly would by and 5 - certainly would not by, they showed their intention of purchasing the product. To conduct the sensory analysis, this project had been previously approved by the Research Ethics Committee of UNESP/Ibilce (no. 58925516.9.0000.5466).

\subsection{Microstructure}

The microstructure of the restructured cooked ham samples was obtained after fifteen days of refrigerated storage using a LEO $450 \mathrm{VPi}$ scanning electron microscope (Zeiss, Oberkochen, Germany) following the procedure described by Totosaus and Pérez-Chabela (2009) with some modifications. The samples were cut into fillets of $4 \mathrm{~mm} \times 2 \mathrm{~mm} \times 2 \mathrm{~mm}$ taken from inside the product and immersed in $2.5 \%$ glutaraldehyde in $0.1 \mathrm{M}$ phosphate buffer for $24 \mathrm{~h}$ for fixation. The samples were washed with $0.1 \mathrm{M}$ sodium phosphate buffer solution and remained in a refrigerator for $2 \mathrm{~h}$ in a solution of osmium tetroxide in $0.1 \mathrm{M}$ phosphate buffer. They were subsequently dehydrated in a series of increasing concentrations of ethanol (30\%, 50\%, 70\%, 90\% and $100 \%$ ethanol). They were then dried by the critical point method using $\mathrm{CO}_{2}$, arranged on aluminum stubs and coated with gold. Observations were then made using the SEM.

\subsection{Statistical analysis}

The results were expressed as the mean values and the standard error of the mean. Each triplicate was included as a random term, and different time were included as fixed term. The data obtained on physicochemical properties (instrumental color, texture profile analysis, TFR and TBARS) were analyzed statistically using mixed model ANOVA analyses and the means were compared using the Tukey test $(P<.05)$.

For the sensory test, the treatment was considered as the main effect and consumers as random variable. The data obtained in the sensorial analysis were analyzed statistically using mixed model ANOVA and the means were compared using the Tukey test $(\mathrm{P}<.05)$. The results were expressed as the mean values and standard error of mean.

All statistical analysis was performed using Statistica 7.0 software (Statsoft Inc., USA).

\section{Results and discussion}

\subsection{Physicochemical properties}

The proximate analysis, $\mathrm{pH}$ and sodium content are shown in Table 2. In all treatments, the amounts of moisture and lipid were similar $(P>.05)$. The protein content of all treatments was within the standards established by Brazilian legislation - a minimum of $14 \%$ (Brazil, 2000). The average values of protein content were from 16.42 to $17.40 \%$. This variation is due to innate differences in the raw material. However, the T100 sample had less protein than the T75 and T50US $(P<.05)$, but did not differ $(P>.05)$ from the T50 samples. Stanley, Bower, and Sullivan (2017) found no differences in protein content between samples of pork sausage patties with reduction of sodium and Yotsuyanagi et al. (2016) reported the same on reducing the $\mathrm{NaCl}$ in frankfurters.

For the ash content, the T100 sample was higher $(P<.05)$ than the other treatments, probably due to the higher salt content used in the formulation of this sample. Similar results were obtained by Yotsuyanagi et al. (2016) who showed that, by increasing the $\mathrm{NaCl}$ in frankfurters by $57 \%$, there was an $18 \%$ increase in the ash content produced.

The results for the analysis of the sodium content (Table 2) show a significant decrease $(P<.05)$ between T100, T75 and T50. T50US and 
Table 2

Proximate analysis, $\mathrm{pH}$ and sodium content of cooked ham with salt reduction including application of ultrasound $(n=3)$.

\begin{tabular}{|c|c|c|c|c|c|c|}
\hline & \multicolumn{4}{|c|}{ Treatments } & \multirow[t]{2}{*}{ SEM } & \multirow[t]{2}{*}{$P$ value } \\
\hline & $\mathrm{T} 100$ & $\mathrm{~T} 75$ & T50 & T50US & & \\
\hline \multicolumn{7}{|l|}{$\begin{array}{l}\text { Proximate composition } \\
\quad(\%)\end{array}$} \\
\hline Moisture & $76.65^{\mathrm{a}}$ & $76.35^{\mathrm{a}}$ & $76.91^{\mathrm{a}}$ & $76.31^{\mathrm{a}}$ & 0.107 & 0.14 \\
\hline Lipid & $3.57^{\mathrm{a}}$ & $3.60^{\mathrm{a}}$ & $3.78^{\mathrm{a}}$ & $3.77^{\mathrm{a}}$ & 0.138 & 0.95 \\
\hline Protein & $16.42^{\mathrm{b}}$ & $17.40^{\mathrm{a}}$ & $16.81^{\mathrm{ab}}$ & $17.35^{\mathrm{a}}$ & 0.139 & $<0.01$ \\
\hline Ash & $3.05^{\mathrm{a}}$ & $2.38^{\mathrm{b}}$ & $2.17^{\mathrm{bc}}$ & $2.06^{\mathrm{c}}$ & 0.120 & $<0.01$ \\
\hline Carbohydrate & 0.31 & 0.27 & 0.33 & 0.51 & & \\
\hline $\mathrm{pH}$ & $6.10^{\mathrm{ab}}$ & $6.25^{\mathrm{a}}$ & $6.02^{\mathrm{b}}$ & $6.01^{\mathrm{b}}$ & 0.035 & 0.025 \\
\hline $\begin{array}{l}\text { Sodium (mg sodium/ } \\
\quad 100 \mathrm{~g} \text { ) }\end{array}$ & $996.52^{\mathrm{a}}$ & $837.60^{b}$ & $676.84^{c}$ & $715.34^{\mathrm{c}}$ & 38.00 & $<0.01$ \\
\hline
\end{tabular}

a-c Mean values in the same line not followed by a common letter differ significantly $(\mathrm{P}<.05)$.

SEM: standard error of the mean.

$\mathrm{T} 100=1.5 \% \mathrm{NaCl} ; \mathrm{T} 75=1.12 \% \mathrm{NaCl} ; \mathrm{T} 50=0.75 \% \mathrm{NaCl} ; \mathrm{T} 50 \mathrm{US}=0.75 \%$ $\mathrm{NaCl}$ and ultrasound.

T50 did not differ $(P>.05)$ from each other, since both had the same percentage of $\mathrm{NaCl}$ in their formulations. T75 showed a reduction of $16 \%$ of sodium, T50 of $32 \%$ and T50US of $28.5 \%$. Therefore, reductions of $25 \%$ and $50 \%$ of salt in the formulations of restructured cooked ham products produced reduced sodium contents of $16 \%$ and $28.5 \%$ respectively. Similar results were obtained by Carraro, Machado, Espindola, Campagnol, and Pollonio (2012) who studied the effects of lowering $\mathrm{NaCl}$ in bologna sausage, where they reported that $50 \%$ salt gave a reduction of $31 \%$ in the sodium content in the final product. Yotsuyanagi et al. (2016) reported that a reduction of $57 \% \mathrm{NaCl}$ in frankfurters led to a $36 \%$ reduction in the sodium content of the final product.

\subsection{Total fluid release (TFR)}

The reduction in salt affected $(P<.05)$ the TFR in restructured cooked ham (Table 3 ). Sodium chloride aids in the extraction and solubility of myofibrillar proteins by increasing the ionic strength, improving its properties as an emulsifier, binder and also its water retention capacity (Ruusunen \& Puolanne, 2005). In this context, the salt reduction in restructured cooked ham means an increase in the TFR. Li, Kang, Zou, Xu, and Zhou (2015) worked with chicken breast meat batter with reduced salt and observed a reduction in the water retention capacity when the salt concentration was decreased from $2 \%$ to $1 \%$. On the other hand, the use of ultrasound technology has reduced the TFR since T50US is not different $(P>.05)$ from the T100 and T75 on day zero or from T75 after sixty days. McClements (1995) reported that ultrasound helped with the extraction of myofibrillar proteins, which have the property of linking themselves to water, increasing thereby the water holding capacity. The increase in water holding capacity improved the TFR results.

An increase in the salt concentration in the pork during curing, following treatment with high power ultrasound, has been reported by several studies (Cárcel, Benedito, Bon, \& Mulet, 2007; Ojha, Keenan, Bright, Kerry, \& Tiwari, 2016; Ozuna, Puig, García-Pérez, Mulet, \& Cárcel, 2013). Siró et al. (2009) observed more diffusion of salt due to treatment with ultrasound compared with curing under static conditions. The authors also concluded that the diffusion coefficient increased along with the increase of ultrasonic intensity $\left(2-4 \mathrm{~W} . \mathrm{cm}^{-2}\right)$ at a frequency of $20 \mathrm{kHz}$. In a study on the effect of ultrasound on salt distribution in salted meat, Cárcel, Benedito, Bon, and Mulet (2007) reported that intensities above $51 \mathrm{~W} . \mathrm{cm}^{-2}$ showed significant mass transfer of $\mathrm{NaCl}$ in the meat. Increased diffusion of salt in the meat matrix assists in the extraction of myofibrillar proteins, which increases the bonding power with water, thereby reflecting a decrease in the TFR. All the treatments increased the TFR $(P<.05)$ during the storage.

\subsection{Instrumental color}

The reduction of $50 \%$ of salt increased the lightness on day 0 of storage (Table 3). A similar result was found by Horita, Messias, Morgano, Hayakawa, and Pollonio (2014) who worked with sausages with salt reduction from $2 \%$ to 1.5 and $1 \%$ salt. With the use of ultrasound in restructured cooked ham with $50 \%$ reduced salt, no difference was found $(P<.05)$ for lightness compared with T100, showing that ultrasound positively contributes $(P<.05)$ to this parameter. After sixty days of storage, T100 had a lower lightness $(P<.05)$ than the other treatments, and there was no difference $(P>.05)$ between treatments with reduced salt and with the use of ultrasound showing that, for all treatments with reduced salt, the lightness increased. The lightness was reduced after sixty days of storage $(P<.05)$, except for T75 for which the lightness had increased after sixty days of storage.

The instrumental color data showed that redness significantly $(P<.05)$ decreased in restructured cooked ham when salt was reduced by $50 \%$ (T50) (Table 3 ). However the redness was similar $(P>.05)$ when the salt reduction was $25 \%$ (T75). These values are in agreement with other authors (Dimitrakopoulou, Ambrosiadis, Zetou, \& Bloukas, 2005; Pires et al., 2017) who observed a decrease in redness with salt reduction. Dimitrakopoulou, Ambrosiadis, Zetou, and Bloukas (2005) showed that restructured pork shoulder decreased its redness when the added salt was reduced from $2 \%$ to $1 \%$. Pires et al. (2017) showed that the reduction of 20,40 and $60 \%$ of sodium in bologna sausage decreased the redness when compared to the control sample. The use of ultrasound in restructured cooked ham with $50 \%$ salt reduction (T50US) increased redness on day 0 , when compared to T50, since, at this time of storage, T50US was lower $(P>.05)$ to T100 and T75. However, after 60 days, T50 and T50US showed similar values for redness $(P>.05)$ and they were both lower $(P<.05)$ than T100. Different results were obtained by Ferrentino and Spilimbergo (2016), who analyzed the combined treatment of high pressure carbon dioxide and high power ultrasound on restructured cooked hams. They reported that samples with and without treatment did not differ $(P>.05)$ for redness at 0 weeks of storage. However, after 1 and 4 weeks of storage, the samples subjected to the processing had lower $(P<.05)$ values for redness. The ultrasound can enhance the salt diffusion into the meat matrix because of $\mathrm{NaCl}$ mass transfer (Ojha, Keenan, Bright, Kerry, \& Tiwari, 2016) and this can increase the extraction of myofibrillar proteins (Vimini, Kemp, \& Fox, 1983). The 50\% reduction of salt increased yellowness at day 0 of storage (with or without ultrasound). After 60 days of storage, more yellowness was observed for T100. The use of ultrasound did not affect the yellowness during storage. Other studies have not confirmed the color effect when ultrasound was used (Jayasooriya, Torley, D'arcy, \& Bhandari, 2007; McDonnell, Lyng, \& Allen, 2014b; Stadnik \& Dolatowski, 2011).

\subsection{Texture profile analysis (TPA)}

Significant changes to hardness were observed in T50US (Table 3) at day 0 and after 60 days of refrigerated storage. The treatment with ultrasound significantly increased $(P<.05)$ the hardness in restructured cooked ham with $50 \%$ salt reduction and it was similar to the control treatment (T100) and T75. There was no difference between T75 and T50 $(P>$.05). Similarly, Ojha, Keenan, Bright, Kerry, and Tiwari (2016) observed a significant improvement in the WarnerBratzler shear force in pork meat when ultrasound was used. These same authors observed that ultrasound can improve the texture while enhancing salt diffusion. The reduction of salt showed significant $(P<.05)$ reduction in the hardness of the restructured cooked ham on day 0 when compared to T100. According to Çarkcioğlu, Rosenthal, and Candoğan (2016), changes in hardness or other parameters in meat 
Table 3

Color parameters, TFR, TPA and the TBARS of cooked ham with salt reduction including application of ultrasound (n $=3$ ).

\begin{tabular}{|c|c|c|c|c|c|c|c|}
\hline & \multirow[t]{2}{*}{ Day } & \multicolumn{4}{|c|}{ Treatments } & \multirow[t]{2}{*}{ SEM } & \multirow[t]{2}{*}{$P$ value } \\
\hline & & $\mathrm{T} 100$ & $\mathrm{~T} 75$ & $\mathrm{~T} 50$ & T50US & & \\
\hline $\mathrm{L}^{*}$ & 0 & $64.14^{\mathrm{b}, \mathrm{A}}$ & $63.03^{\mathrm{b}, \mathrm{B}}$ & $69.16^{\mathrm{a}, \mathrm{A}}$ & $64.92^{\mathrm{b}, \mathrm{A}}$ & 0.372 & $<0.01$ \\
\hline $\mathrm{L}^{*}$ & 60 & $60.79^{\mathrm{b}, \mathrm{B}}$ & $64.57^{\mathrm{a}, \mathrm{A}}$ & $65.85^{\mathrm{a}, \mathrm{B}}$ & $64.57^{\mathrm{a}, \mathrm{B}}$ & 0.385 & $<0.01$ \\
\hline$P$ value & & $<0.01$ & $<0.01$ & $<0.01$ & $<0.01$ & & \\
\hline$a^{*}$ & 0 & $12.18^{\mathrm{a}, \mathrm{B}}$ & $12.05^{\mathrm{a}, \mathrm{A}}$ & $9.37^{\mathrm{c}, \mathrm{B}}$ & $10.92^{\mathrm{b}, \mathrm{A}}$ & 0.204 & $<0.01$ \\
\hline$a^{*}$ & 60 & $13.61^{\mathrm{a}, \mathrm{A}}$ & $11.83^{\mathrm{b}, \mathrm{B}}$ & $10.85^{\mathrm{c}, \mathrm{A}}$ & $11.41^{\mathrm{bc}, \mathrm{A}}$ & 0.172 & $<0.01$ \\
\hline$P$ value & & $<0.01$ & $<0.01$ & $<0.01$ & 0.14 & & \\
\hline$b^{*}$ & 0 & $8.31^{\mathrm{b}, \mathrm{B}}$ & $8.63^{\mathrm{ab}, \mathrm{B}}$ & $9.64^{\mathrm{a}, \mathrm{A}}$ & $9.31^{\mathrm{a}, \mathrm{A}}$ & 0.095 & $<0.01$ \\
\hline$b^{*}$ & 60 & $9.67^{\mathrm{a}, \mathrm{A}}$ & $9.21^{\mathrm{b}, \mathrm{A}}$ & $9.32^{\mathrm{ab}, \mathrm{A}}$ & $9.23^{\mathrm{ab}, \mathrm{A}}$ & 0.065 & 0.03 \\
\hline$P$ value & & $<0.01$ & $<0.01$ & 0.15 & 0.71 & & \\
\hline TFR (\%) & 0 & $0.03^{\mathrm{b}, \mathrm{B}}$ & $0.32^{\mathrm{b}, \mathrm{B}}$ & $2.74^{\mathrm{a}, \mathrm{B}}$ & $0.56^{\mathrm{b}, \mathrm{B}}$ & 0.411 & $<0.01$ \\
\hline TFR (\%) & 60 & $0.21^{\mathrm{c}, \mathrm{A}}$ & $0.65^{\mathrm{bc}, \mathrm{A}}$ & $3.12^{\mathrm{a}, \mathrm{A}}$ & $1.17^{\mathrm{b}, \mathrm{A}}$ & 0.421 & $<0.01$ \\
\hline$P$ value & & $<0.01$ & $<0.01$ & $<0.01$ & $<0.01$ & & \\
\hline Hardness (N) & 0 & $21.01^{\mathrm{a}, \mathrm{A}}$ & $17.14^{\mathrm{ab}, \mathrm{B}}$ & $12.61^{\mathrm{b}, \mathrm{B}}$ & $22.83^{\mathrm{a}, \mathrm{B}}$ & 1.253 & $<0.01$ \\
\hline Hardness (N) & 60 & $26.97^{\mathrm{ab}, \mathrm{A}}$ & $26.70^{\mathrm{ab}, \mathrm{A}}$ & $23.28^{\mathrm{b}, \mathrm{A}}$ & $35.26^{\mathrm{a}, \mathrm{A}}$ & 1.497 & 0.05 \\
\hline$P$ value & & 0.06 & $<0.01$ & $<0.01$ & 0.02 & & \\
\hline Cohesiveness & 0 & $0.31^{\mathrm{a}, \mathrm{A}}$ & $0.36^{\mathrm{a}, \mathrm{A}}$ & $0.30^{\mathrm{a}, \mathrm{B}}$ & $0.40^{\mathrm{a}, \mathrm{A}}$ & 0.017 & 0.11 \\
\hline Cohesiveness & 60 & $0.38^{\mathrm{a}, \mathrm{A}}$ & $0.44^{\mathrm{a}, \mathrm{A}}$ & $0.40^{\mathrm{a}, \mathrm{A}}$ & $0.36^{\mathrm{a}, \mathrm{A}}$ & 0.015 & 0.26 \\
\hline$P$ value & & 0.12 & 0.16 & $<0.01$ & 0.42 & & \\
\hline Springiness & 0 & $0.67^{\mathrm{a}, \mathrm{B}}$ & $0.70^{\mathrm{a}, \mathrm{A}}$ & $0.67^{\mathrm{a}, \mathrm{A}}$ & $0.64^{\mathrm{a}, \mathrm{A}}$ & 0.013 & 0.52 \\
\hline Springiness & 60 & $0.77^{\mathrm{a}, \mathrm{A}}$ & $0.71^{\mathrm{a} b, \mathrm{~A}}$ & $0.66^{\mathrm{b}, \mathrm{A}}$ & $0.65^{\mathrm{b}, \mathrm{A}}$ & 0.012 & $<0.01$ \\
\hline$P$ value & & $<0.01$ & 0.87 & 0.75 & 0.79 & & \\
\hline Chewiness & 0 & $4.59^{\mathrm{ab}, \mathrm{B}}$ & $4.27^{\mathrm{b}, \mathrm{B}}$ & $2.57^{\mathrm{b}, \mathrm{B}}$ & $7.69^{\mathrm{a}, \mathrm{A}}$ & 0.514 & $<0.01$ \\
\hline Chewiness & 60 & $8.00^{\mathrm{a}, \mathrm{A}}$ & $8.52^{\mathrm{a}, \mathrm{A}}$ & $6.38^{\mathrm{a}, \mathrm{A}}$ & $9.91^{\mathrm{a}, \mathrm{A}}$ & 0.667 & 0.35 \\
\hline$P$ value & & $<0.01$ & $<0.01$ & $<0.01$ & 0.42 & & \\
\hline TBARS* & 0 & $0.05^{\mathrm{a}, \mathrm{B}}$ & $0.03^{\mathrm{a}, \mathrm{B}}$ & $0.03^{\mathrm{a}, \mathrm{B}}$ & $0.05^{\mathrm{a}, \mathrm{B}}$ & 0.005 & 0.09 \\
\hline TBARS* & 60 & $0.14^{\mathrm{a}, \mathrm{A}}$ & $0.16^{\mathrm{a}, \mathrm{A}}$ & $0.14^{\mathrm{a}, \mathrm{A}}$ & $0.17^{\mathrm{a}, \mathrm{A}}$ & 0.007 & 0.34 \\
\hline$P$ value & & $<0.01$ & $<0.01$ & $<0.01$ & $<0.01$ & & \\
\hline
\end{tabular}

a-c Mean values in the same line not followed by a common letter differ significantly $(\mathrm{P}<.05)$.

A-B Mean values in the same column not followed by a common letter differ significantly $(\mathrm{P}<.05)$.

SEM: standard error of the mean.

*expressed in mg MDA. $\mathrm{Kg}^{-1}$ sample.

$\mathrm{T} 100=1.5 \% \mathrm{NaCl} ; \mathrm{T} 75=1.12 \% \mathrm{NaCl} ; \mathrm{T} 50=0.75 \% \mathrm{NaCl} ; \mathrm{T} 50 \mathrm{US}=0.75 \% \mathrm{NaCl}$ and ultrasound

products are associated with differences in the water holding capacity. Salt is used to solubilize myofibrillar proteins in meat systems, increasing the water holding capacity and improving the texture (Desmond, 2006). Others studies have shown the opposite effect on hardness (Horita, Messias, Morgano, Hayakawa, \& Pollonio, 2014). The hardness increased $(P<.05)$ after 60 days of storage even when salt was reduced from 75 to $50 \%$. The highest values observed for TRF after 60 days of storage, possibly contributed to the increased hardness of these samples after 60 days of storage, due to the loss of water.

There were no significant differences $(P>.05)$ among the treatments in cohesiveness (Table 3). Similar results were reported by Barekat and Soltanizadeh (2017), who evaluated the texture of meat subjected to ultrasound and there were no differences in the cohesiveness of the meat compared to the control. In another study, McDonnell, Lyng, and Allen (2014b), when evaluating the texture profile of pork with curing accelerated by ultrasound, observed a small reduction in cohesiveness in the samples subjected to ultrasound. For the springiness, there were no significant differences $(P>.05)$ between the treatments on day zero of storage but, after sixty days, the lowest springiness values were for T50 and T50US, i.e. the salt reduction resulted in decreased springiness. In studies of sodium reduction in frankfurters, the parameters of hardness, springiness, cohesiveness and chewiness were not affected by the other ingredients in the formulation, such as increased soy protein to increase gel formation (Yotsuyanagi et al., 2016).

Chewiness was not affected by the reduction of salt in restructured cooked ham during refrigerated storage (Table 3). The use of ultrasound significantly $(P<.05)$ increased the chewiness at day 0 and it was higher than T50, but after 60 days there was no significant difference.

\subsection{TBARS}

The salt reduction at $25 \%$ and $50 \%$ and treatment with ultrasound did not affect the oxidative stability of restructured cooked ham after 0 and 60 days of storage (Table 3). The values found in this study ranged from 0.03 to $0.17 \mathrm{mg}$ malonaldehyde / $\mathrm{kg}$ sample, showing that there wasn't any alteration to the flavor originating from lipid oxidation. According to O'Neill, Galvin, Morrissey, and Buckley (1998), TBARS values from 0.5 to $2.0 \mathrm{mg} \cdot \mathrm{kg}^{-1}$ do not affect the sensory acceptance. The low percentage of the lipids in restructured cooked ham and the controlled temperature during processing in the present research may have contributed to such oxidation results. The storage time showed an increase $(P<.05)$ in the values of TBARS for all treatments. Coombs et al. (2018) also reported an increase in TBARS levels on lamb $M$. longissimus lumborum after four weeks of refrigerated store.

\subsection{Microstructure of restructured cooked ham}

The SEM technique showed (Fig. 1) the effect of the ultrasound on the restructured cooked ham microstructure. The micrograph of the T50US sample (Fig. 1d), treated for $10 \mathrm{~min}$ with a nominal current of 600 W.cm ${ }^{-2}$ shows ruptures and greater dispersion of connective tissue fibers caused by the application of ultrasound when compared to images of the treatments without the use of this technology (1a, 1b and 1c). Some micro fissures on myofibril were identified in the same Fig. (1d) caused by acoustic energy of ultrasound, i.e. cavitation. Cavitation occurs when the ultrasonic wave passes through a liquid medium, causing alternating compression and rarefaction waves, producing bubbles in the liquid until implosion occurs, providing a localized pressure and temperature rise and the production of micro jets that generate sufficient power to disrupt cells (Chemat, Zill, \& Khan, 2011.; 

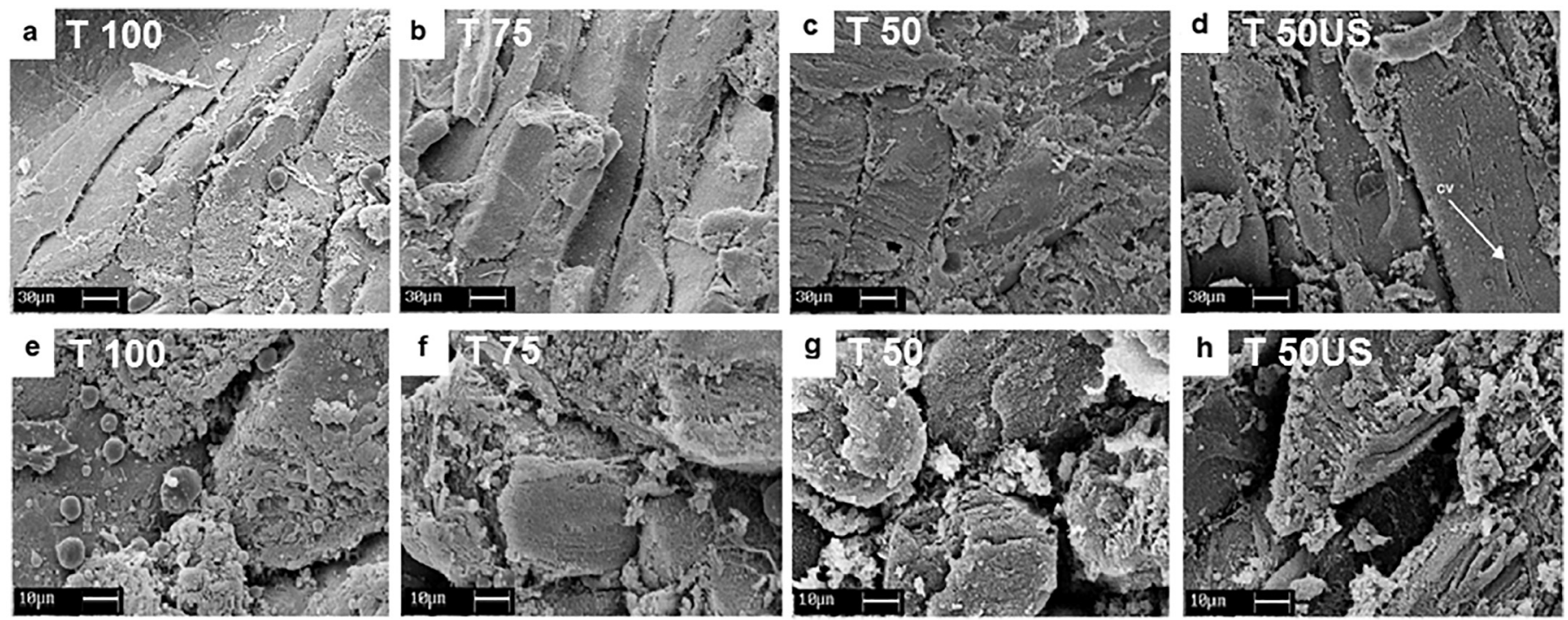

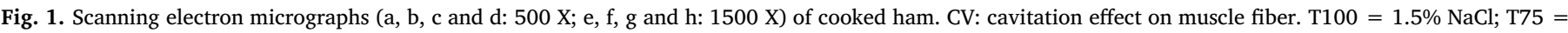
$1.12 \% \mathrm{NaCl}$; T50 $=0.75 \% \mathrm{NaCl}$; T50US $=0.75 \% \mathrm{NaCl}$ and ultrasound.

Cárcel, García-Pérez, Benedito, \& Mulet, 2012). The micro jets, caused by imploding bubbles, collide with the surface of the myofibrils, causing micro fissures and changing the product structure. Similar effects were described by Ozuna, Puig, García-Pérez, Mulet, and Cárcel (2013) when evaluating the effect of ultrasound treatment on the static moist curing of pork. In Fig. $1 \mathrm{~h}$, note the greater spacing between the myofibrils compared to other images (Fig. 1e, f and g) which did not have the ultrasound treatment. Siró et al. (2009) also observed a greater distance between the myofibrils in pork loins subjected to static moist curing and treated with ultrasound. For these authors, cavitation caused by the ultrasound opens channels between the myofibrils, which facilitate the penetration of brine, called the "sponge effect". Larger interfibrillar spaces allow more water retention in the product, which could minimize the weight loss during storage. This sponge effect, observed in restructured cooked ham with reduced salt and with the use of ultrasound, can also be explained by the lower TFR obtained in this treatment (Table 3) as previously mentioned.

\subsection{Microbiological analysis}

The results of the microbiological evaluations showed no differences between periods of zero and sixty days of storage. For all treatments in both periods, the growth of coliforms at $45^{\circ} \mathrm{C}$ was $<3 \mathrm{NMP} / \mathrm{g}$, coagulase positive Staphylococci was $<10^{2} \mathrm{CFU} / \mathrm{g}$, anaerobic count of sulfite reducing Clostridia at $46^{\circ} \mathrm{C}$ was $10^{1} \mathrm{CFU} / \mathrm{g}$ and Salmonella sp. was absent in $25 \mathrm{~g}$ of sample. The results are within the limits established in Brazilian legislation for this product (Brazil, 2001).

\subsection{Sensory acceptance}

Regarding the sensory color, T100 had a higher score $(P<.05)$ than T50 and T50US and did not differ $(P>.05)$ from T75 (Table 4$)$. The reduction of $50 \% \mathrm{NaCl}$ reduced the score for color in restructured cooked ham. Similar results were reported by Zanardi, Ghidini, Conter, and Ianieri (2010) that, by reducing the $\mathrm{NaCl}$ concentration of Italian salami by $50 \%$, there were lower scores for color compared to the control. The treatment with ultrasound (T50US), did not improve the color scores for restructured cooked ham when compared to T50, with the same $\mathrm{NaCl}$ concentration (Table 4). With regard to taste, T50 showed a lower score, differing from all other treatments $(P<.05)$, showing that the use of ultrasound improved this attribute. The reduction of $50 \%$ of salt produced a lower score $(P<.05)$. Yotsuyanagi
Table 4

Sensory acceptance of cooked ham with salt reduction including application of ultrasound.

\begin{tabular}{lcccccc}
\hline \multicolumn{2}{l}{ Treatments } & & & \multirow{2}{*}{ SEM } & P value \\
& T100 & T75 & T50 & T50US & & \\
\cline { 1 - 4 } & & & & & & \\
Sensorial acceptance & & & & & \\
$\quad$ Color & $7.83^{\mathrm{a}}$ & $7.70^{\mathrm{a}}$ & $7.30^{\mathrm{b}}$ & $7.32^{\mathrm{b}}$ & 0.059 & $<0.01$ \\
Taste & $7.54^{\mathrm{a}}$ & $7.32^{\mathrm{a}}$ & $6.66^{\mathrm{b}}$ & $7.21^{\mathrm{a}}$ & 0.063 & $<0.01$ \\
Texture & $7.67^{\mathrm{a}}$ & $7.40^{\mathrm{a}}$ & $6.97^{\mathrm{b}}$ & $7.31^{\mathrm{ab}}$ & 0.065 & $<0.01$ \\
Global acceptance & $7.57^{\mathrm{a}}$ & $7.37^{\mathrm{a}}$ & $6.76^{\mathrm{b}}$ & $7.28^{\mathrm{a}}$ & 0.060 & $<0.01$ \\
Purchase intention & $4.07^{\mathrm{a}}$ & $3.95^{\mathrm{a}}$ & $3.49^{\mathrm{b}}$ & $3.97^{\mathrm{a}}$ & 0.041 & $<0.01$
\end{tabular}

a-b Mean values in the same line not followed by a common letter differ significantly $(\mathrm{P}<.05)$.

SEM: standard error of the mean.

$\mathrm{T} 100=1.5 \% \mathrm{NaCl} ; \mathrm{T} 75=1.12 \% \mathrm{NaCl} ; \mathrm{T} 50=0.75 \% \mathrm{NaCl} ; \mathrm{T} 50 \mathrm{US}=0.75 \%$ $\mathrm{NaCl}$ and ultrasound.

et al. (2016) also observed a significant reduction in score for the taste when studying frankfurters with $1 \%$ salt compared to $1.3 \%$ and $1.75 \%$ salt. T50US, T75 and T100 were not different $(P>.05)$ in terms of taste for sensory acceptance. The restructured cooked ham with $50 \%$ sodium chloride solution subjected to ultrasound provided the same sensory acceptance for taste in relation to the restructured cooked ham without sodium reduction, probably due to better diffusion of salt in the meat matrix.

For texture, T 50 was less accepted $(P<.05)$ than T100 and T75, indicating that the reduction of $\mathrm{NaCl}$ decreased the score for texture. However, T50US did not differ $(P>.05)$ from T100 and T75, showing that the use of ultrasound contributed to scores for texture similar to higher salt levels in restructured cooked ham formulations. The 50\% salt sample $(\mathrm{T} 50)$ had significantly reduced $(P<.05)$ global acceptance (Table 4). These results are in agreement with the results obtained in other studies (Horita, Messias, Morgano, Hayakawa, \& Pollonio, 2014; Pires et al., 2017; Yotsuyanagi et al., 2016). This effect is due to the fact that salt reduction in meat products decreases the extraction of myofibrillar proteins, reducing the ionic strength and consequently reducing the water retention capacity of the system, affecting the formation of the protein network with heat treatment and maybe increasing drip losses during storage and thus affecting product texture (Tamm, Bolumar, Bajovic, \& Toepfl, 2016).

In this study, ultrasound treatment has improved the sensory 
acceptance of taste, texture and global acceptance and increased the purchase intent of restructured cooked ham with $50 \%$ salt reduction, possibly due to better diffusion of the salt which is produced by the use of ultrasound. McDonnell, Lyng, Arimi, and Allen (2014a) produced restructured cooked ham with $2.25 \%$ sodium chloride and subjected three treatments to ultrasound (10.7; 17.1 and $25.4 \mathrm{~W} . \mathrm{cm}^{-2}$ ) and a control, after 2, 4 and $6 \mathrm{~h}$. On applying the sensory analysis, the authors reported significant improvement in taste with increasing intensity of the ultrasound. Ozuna, Puig, García-Pérez, Mulet, and Cárcel (2013) corroborate this fact by finding improved diffusion of $\mathrm{NaCl}$ and moisture in the meat, caused by cavitation, a result of the acoustic treatment. Ojha, Keenan, Bright, Kerry, and Tiwari (2016) investigated the $\mathrm{NaCl}$ diffusion in pork subjected to different strengths of ultrasound. The authors concluded that with $54.9 \mathrm{~W} . \mathrm{cm}^{-2}$ power, the diffusion coefficient of $\mathrm{NaCl}$ in the meat was significantly higher than the control without the use of ultrasound. McClements (1995) reported that ultrasound also facilitated the extraction of myofibrillar proteins, which have properties linked to water, increasing thereby the water retention capacity. All the ultrasound properties described above contributed to increasing the acceptance of texture and also the global acceptance in this study.

\section{Conclusion}

The ultrasound helps by improving the quality of restructured cooked ham with reduced sodium chloride at low levels, showing good potential for application in the development of other healthier meat products. Restructured cooked ham was produced with a reduction of $50 \%$ in the added salt and with sodium content reduced by $32 \%$ with ultrasound application. There was no impairment of the physicochemical and sensory properties. The use of ultrasound improved the physicochemical properties in restructured cooked ham with reduced sodium, such as reducing Total Fluid Release, increasing the yield, improving the color and without negatively affecting the oxidative stability. The ultrasound modified the microstructure of restructured cooked ham by producing microfissures in the muscle fibers and this improved sensory acceptance for taste and texture parameters and for global acceptance.

\section{Chemical compounds used in this research}

Sodium acetate (PubChem CID: 517045); Methanol (PubChem CID: 887); Chloroform (PubChem CID: 6212); Sodium Carbonate (PubChem CID: 10340); Thiobarbituric acid (PubChem CID: 2723628); Glacial acetic acid (PubChem CID: 176); Sodium hydroxide (PubChem CID: 14798); Trichloroacetic acid (PubChem CID: 6421); Tetraethoxypropane (PubChem CID: 67147); Boric acid (PubChem CID: 7628).

\section{References}

ABPA. Brazilian Association of Animal Protein. Annual Report 2016. Available < http:// abpa-br.com.br/setores/suinocultura/publicacoes/relatoriosanuais/2016 > . Acessed in May 10, 2017.

AOAC (2007). Official methods of analysis of AOAC (Association of Official Analytical Chemists) international (18th ed.). Gaithersburg, MD: AOAC International.

Askar, A., El-Samahi, S. K., \& Tawfic, M. (1994). Pasterna and beef bouillon. The effect of substituting $\mathrm{KCl}$ and K-lactate for sodium chloride. Fleischwirtschaft, 73(3), 289-292.

Barekat, S., \& Soltanizadeh, N. (2017). Improvement of meat tenderness by simultaneous application of high-intensity ultrasonic radiation and papain treatment. Innovative Food Science \& Emerging Technologies, 39, 223-229.

Bis, C. V., Barretto, T. L., Henck, J. M. M., Mathias, J. C., Oliveira, L. S., \& Barretto, A. C. S. (2016). Physicochemical characteristics and sensory acceptability of ready-to-eat sliced frozen roast beef with partial reduction of sodium chloride. Food Science and Technology, 36(2), 286-289.

Bligh, E. G., \& Dyer, W. J. (1959). A rapid method of total lipid extraction and purification. Canadian Journal of Biochemistry and Physiology, 37, 911-917.

Bourne, M. C. (1978). Texture profile analysis. Food Technology, 32(7), 62-66.

Brazil. Ministry of Agriculture Livestock and Food Supply. Normative Instruction $n^{\circ} 20$, July 31 , 2000. Technical Regulation of Identity and Quality of cooked restructured pork shoulder.
(2000). http://extranet.agricultura.gov.br/sislegisconsulta/consultarLegislacao.do? operacao $=$ visualizar\&id $=1681>$, Accessed date: 23 March 2017 (Available).

Brazil (2001). Ministry of Health. Resolução RDC n.12 de 02 de janeiro de 2001. Regulamento Técnico sobre padrões para alimentos. (Available) http://portal.anvisa. gov.br/documents/33880/2568070/RDC_12_2001.pdf/15ffddf6-3767-4527-bfac740a0400829b > , Accessed date: 12 March 2017.

Bruna, J. M., Ordonez, J. A., Fernández, M., Herranz, B., \& La Roz, L. (2001). Microbial and physico-chemical changes during the ripening of dry fermented sausages superficially inoculated with or having added an intracellular cell-free extract of Penicillium aurantiogriseum. Meat Science, 59(1), 87-96.

Cárcel, J. A., Benedito, J., Bon, J., \& Mulet, A. (2007). High intensity ultrasound effects on meat brining. Meat Science, 76(4), 611-619.

Cárcel, J. A., García-Pérez, J. V., Benedito, J., \& Mulet, A. (2012). Food process innovation through new technologies: Use of ultrasound. Journal of Food Engineering, 110(2), 200-207.

Carkcioğlu, E., Rosenthal, A. J., \& Candoğan, K. (2016). Rheological and textural properties of sodium reduced salt soluble myofibrillar protein gels containing sodium tripolyphosphate. J. Textural Stud. 47(3), 181-187.

Carraro, C. I., Machado, R., Espindola, V., Campagnol, P. C. B., \& Pollonio, M. A. R. (2012). The effect of sodium reduction and the use of herbs and spices on the quality and safety of bologna sausage. Food Science and Technology, 32(2), 289-295.

Chemat, F., Zill, E. H., \& Khan, M. K. (2011). Applications of ultrasound in food technology: Processing, preservation and extraction. Ultrasonics Sonochemistry, 18(4), 813-835.

Coombs, C. E. O., Holmana, B. W. B., Ponnampalam, E. N., Morris, S., Friend, M. A., \& Hopkinsa, D. L. (2018). Effects of chilled and frozen storage conditions on the lamb M. longissimus lumborum fatty acid and lipid oxidation parameters. Meat Science, 136, $116-122$.

Desmond, E. (2006). Reducing salt: A challenge for the meat industry. Meat Science, 74(1), $188-196$.

Dimitrakopoulou, M. A., Ambrosiadis, J. A., Zetou, F. K., \& Bloukas, J. G. (2005). Effect of salt and transglutaminase (TG) level and processing conditions on quality characteristics of phosphate-free, cooked, restructured pork shoulder. Meat Science, 70(4), 743-749.

Ferrentino, G., \& Spilimbergo, S. (2016). A combined high pressure carbon dioxide and high power ultrasound treatment for the microbial stabilization of cooked ham. Journal of Food Engineering, 174, 47-55.

Geleijnse, J. M., Kok, F. J., \& Grobbee, D. E. (2003). Blood pressure response to changes in sodium and potassium intake: A metaregression analysis of randomised trials. Journal of Human Hypertension, 17(7), 471-480.

Gelabert, J., Gou, P., Guerrero, L., \& Arnau, J. (2003). Effect of sodium chloride replacement on some characteristics of fermented sausages. Meat Science, 65(2), 833-839.

Horita, C. N., Messias, V. C., Morgano, M. A., Hayakawa, F. M., \& Pollonio, M. A. R. (2014). Textural, microstructural and sensory properties of reduced sodium frankfurter sausages containing mechanically deboned poultry meat and blends of chloride salts. Food Research International, 66, 29-35.

Horwitz, W. (2010). Official methods of analysis of the Association of Official Analytical Chemists (18th ed.). Gaithersburg, Maryland: AOAC. Current Through Revision 3 (Chapter 50).

Iser, B. P. M., Claro, R. M., Moura, E. C., Malta, D. C., \& Neto, O. L. M. (2011). Fatores de risco e proteção para doenças crônicas não transmissíveis obtidos por inquérito telefônico. Revista Brasileira de Epidemiologia, 14, 90-112.

Jayasooriya, S. D., Torley, P. J., D'arcy, B. R., \& Bhandari, B. R. (2007). Effect of high power ultrasound and ageing on the physical properties of bovine Semitendinosus and Longissimus muscles. Meat Science, 75(4), 628-639.

Leadley, E., \& Willians, A. (2008). In J. G. Brennam (Ed.). Procesado com pulsos electricos, ultrasonidos de potencia y otras tecnologias emergentes. Manual del procesado de los alimentos. Zaragoza: Acribia.

Li, K., Kang, Z., Zou, Y., Xu, X., \& Zhou, G. (2015). Effect of ultrasound treatment on functional properties of reduced-salt chicken breast meat batter. Journal of Food Science and Technology, 52(5), 2622-2633.

McClements, D. J. (1995). Advances in the application of ultrasound in food analysis and processing. Trends in Food Science and Technology, 6(9), 293-299.

McDonnell, C. K., Lyng, J. G., \& Allen, P. (2014b). The use of power ultrasound for accelerating the curing of pork. Meat Science, 98(2), 142-149.

McDonnell, C. K., Lyng, J. G., Arimi, J., \& Allen, P. (2014a). The accelerated curing of pork using power ultrasound: A pilot-scale production. Innovative Food Science \& Emerging Technologies, 26, 191-198.

Meilgaard, M., Civille, G. V., \& Carr, B. T. (1999). Sensory evaluation techniques (3.ed.). New York: CRC (281 p).

Ojha, K. S., Keenan, D. F., Bright, A., Kerry, J. P., \& Tiwari, B. K. (2016). Ultrasound assisted diffusion of sodium salt replacer and effect on physicochemical properties of pork meat. International Journal of Food Science and Technology, 51(1), 37-45.

O'Neill, L. M., Galvin, K., Morrissey, P. A., \& Buckley, D. J. (1998). Comparison of effects of dietary olive oil, tallow and vitamin $\mathrm{E}$ on the quality of broiler meat products. British Poultry Science, 39, 365-371.

Ozuna, C., Puig, A., García-Pérez, J. V., Mulet, A., \& Cárcel, J. A. (2013). Influence of high intensity ultrasound application on mass transport, microstructure and textural properties of pork meat (longissimus dorsi) brined at different $\mathrm{NaCl}$ concentrations. Journal of Food Engineering, 119(1), 84-93.

Pires, M. A., Munekata, P. E. S., Baldin, J. C., Rocha, Y. J. P., Carvalho, L. T., Santos, I. R., Trindade, M. A. (2017). The effect of sodium reduction on the microstructure, texture and sensory acceptance of Bologna sausage. Food Structure, 14, 1-7.

Ruusunen, M., \& Puolanne, E. (2005). Reducing sodium intake from meat products. Meat Science, $70(3), 531-541$. 
Siró, I., Vén, C. S., Balla, C. S., Jónás, G., Zeke, I., \& Friedrich, L. (2009). Application of an ultrasonic assisted curing technique for improving the diffusion of sodium chloride in porcine meat. Journal of Food Engineering, 91(2), 353-362.

Stadnik, J., \& Dolatowski, Z. J. (2011). Influence of sonication on Warner-Bratzler shear force, colour and myoglobin of beef ( $m$. semimembranosus). European Food Research and Technology, 233, 553-559.

Stanley, R. E., Bower, C. G., \& Sullivan, G. A. (2017). Influence of sodium chloride reduction and replacement with potassium chloride based salts on the sensory and physico-chemical characteristics of pork sausage patties. Meat Science, 133, 36-42.

Tamm, A., Bolumar, T., Bajovic, B., \& Toepfl, S. (2016). Salt (NaCl) reduction in cooked ham by a combined approach of high pressure treatment and the salt replacer $\mathrm{KCl}$. Innovative Food Science \& Emerging Technologies, 36, 294-302.

Totosaus, A., \& Pérez-Chabela, M. L. (2009). Textural properties and microstucture of low-fat and sodium-reduced meat batters formulated with gellan gun and dicationics salts. LWT- Food Science and Technology, 24(2), 563-569.

Válková, V., Saláková, A., Buchtová, H., \& Tremlová, B. (2007). Chemical, instrumental and sensory characteristics of cooked pork ham. Meat Science, 77(4), 608-615.
Vimini, R. J., Kemp, J. D., \& Fox, J. D. (1983). Effects of low frequency ultrasound on properties of restructured beef rolls. Journal of Food Science, 48, 1572-1573.

Vollmer, W. M., Sacks, F. M., Ard, J., Appel, L. J., Bray, G. A., \& Simons-Aaorton, D. G. (2001). Effects of diet and sodium intake on blood pressure: Subgroup analysis of the DASH-sodium trial. Annals of Internal Medicine, 1019-1028(Philadelphia), 135.

Wentzel-Viljoen, E., Steyn, K., Ketterer, E., \& Charlton, K. E. (2013). Use salt and foods high in salt sparingly: A food-based dietary guideline for South Africa. South African Journal of Clinical Nutrition, 26(3), S105-S113.

Yotsuyanagi, S. E., Contreras-Castillo, C. J., Haguiwara, M. M. H., Cipolli, K. M. V. A. B., Lemos, A. L. S. C., Morgano, M. A., \& Yamada, E. A. (2016). Technological, sensory and microbiological impacts of sodium reduction in frankfurters. Meat Science, 115, 50-59.

Zanardi, E., Ghidini, S., Conter, M., \& Ianieri, A. (2010). Mineral composition of Italian salami and effect of $\mathrm{NaCl}$ partial replacement on compositional, physico-chemical and sensory parameters. Meat Science, 86(3), 742-747.

Zipser, M. W., \& Watts, B. M. (1962). A modified 2-thiobarbituric acid (TBA) method for the determination of malonaldehide in cured meats. Food Technology, 16, 102-110. 